\title{
Using Spatial Regression to Model Potentially Toxic Metal (PTM) Mobility Based on Physicochemical Soil Properties
}

\author{
Melissa A. Magno, Arpita Nandi $(\mathbb{D}$, and Ingrid E. Luffman \\ Department of Geosciences, East Tennessee State University, Johnson City 37614, TN, USA \\ Correspondence should be addressed to Arpita Nandi; nandi@etsu.edu
}

Received 3 January 2019; Accepted 10 April 2019; Published 4 August 2019

Academic Editor: Claudio Cocozza

Copyright (C) 2019 Melissa A. Magno et al. This is an open access article distributed under the Creative Commons Attribution License, which permits unrestricted use, distribution, and reproduction in any medium, provided the original work is properly cited.

\begin{abstract}
Mining processes generate waste rock, tailings, and slag that can increase potentially toxic metal (PTM) concentrations in soils. Un-reclaimed, abandoned mine sites are particularly prone to leaching these contaminants, which may accumulate and pose significant environmental and public health concerns. The characterization and spatial delineation of PTMs in soils is vital for risk assessment and soil reclamation. Bumpus Cove, a once active mining district of eastern Tennessee, is home to at least 47 abandoned, un-reclaimed mines, all permanently closed by the 1950s. This study evaluated soil physicochemical properties, determined the spatial extent of PTMs ( $\mathrm{Zn}, \mathrm{Mn}, \mathrm{Cu}, \mathrm{Pb}$, and $\mathrm{Cd}$ ), and examined the influence of soil properties on PTM distribution in Bumpus Cove, TN. Soil samples $(n=52)$ were collected from a $0.67 \mathrm{~km}^{2}$ study area containing 6 known abandoned $\mathrm{Pb}, \mathrm{Zn}$, and $\mathrm{Mn}$ mines at the headwaters of Bumpus Cove Creek. Samples were analyzed for $\mathrm{Zn}, \mathrm{Mn}, \mathrm{Cu}, \mathrm{Pb}$, and $\mathrm{Cd}$ by microwave-assisted acid digestion and flame atomic absorption spectrometry (FAAS) $(12-1,354 \mathrm{mg} / \mathrm{kg} \mathrm{Zn,} \mathrm{6-2,574} \mathrm{mg/kg} \mathrm{Mn,}$ 1-65 mg/kg Cu, 33-2,271 mg/kg Pb, and 7-40 mg/kg Cd). Of the measured PTMs, only Pb exceeds permissible limits in soils. In addition to the PTM analyses, soil physical (texture, moisture content, and bulk density) and chemical ( $\mathrm{pH}$, cation exchange capacity (CEC), and total organic carbon (TOC)) properties were evaluated. Spatially weighted multivariate regression models developed for all PTMs using soil physicochemical properties produced improved results over ordinary least squares (OLS) regression models. Models for $\mathrm{Zn}\left(R^{2}=0.71\right)$ and $\mathrm{Pb}\left(R^{2}=0.69\right)$ retained covariates $e^{\mathrm{pH}}$, moisture content, and $\mathrm{CEC}(\mathrm{Zn})$, and $\mathrm{pH}$ and CEC $(\mathrm{Pb})$. This study will help define PTM concentration and transport and provide a reference for state and local entities responsible for contaminant monitoring in Bumpus Cove, TN.
\end{abstract}

\section{Introduction}

Contamination by potentially toxic metals (PTMs) in soils may develop from either geological or anthropogenic sources, and as they tend to bioaccumulate, they may act as pollutants and give rise to concern regarding human health, agriculture, and ecotoxicology [1]. Natural occurrences of PTMs in soils are strongly associated with the complex distribution of metal-containing parent material, and they become incorporated into the soil by means of weathering processes and/or atmospheric deposition $[2,3]$. Frequency and occurrence of PTM contamination in soils is increased by anthropogenic activities such as the mining of metal ores which generate primary contaminants consisting of waste rock, tailings, and slag. The rate and intensity of PTM pollution is dependent on the relative abundance of individual metals as well as their toxicity, mobility, and bioavailability potential [4]. The most prominent PTMs that accumulate in soils include $\mathrm{Cd}, \mathrm{Cr}, \mathrm{Cu}, \mathrm{Hg}, \mathrm{Ni}, \mathrm{Pb}$, and $\mathrm{Zn}$ [5]. PTMs are different from organic pollutants in that they are not removed by natural attenuation. Instead, they may be concentrated and some of them converted to organic complexes by organisms, thus increasing toxicity [6]. PTMs, classified according to the primary accumulation mechanisms in sediments, have different remobilization behaviors under changing environmental conditions [7]. These contaminants in soils are rarely soluble and primarily occur in a sorbed state or as insoluble compounds, excluding highly acidic soils [8]. Low solubility affects transport in soils, and as demonstrated by Chang et al. [9], more than $90 \%$ of PTMs 
are found in the surface $15 \mathrm{~cm}$ of the soil. Even slow transport through soil and subsoil materials may eventually cause groundwater contamination [8].

Usually, soils surrounding mines and mine tailings are mechanically, physically, chemically, and biologically deficient [10]. These soils are also typically low in nutrients and organic matter and high in PTMs [11]. Therefore, unreclaimed abandoned mine sites may accumulate PTMs in soil and threaten environmental and public health. PTM pollution near abandoned mine sites may vary greatly as a function of numerous variables, which include types and total amounts of ores/minerals mined, materials/chemicals used for processing and treatment, duration since abandonment, major routes of metal transport, and types of vegetation [12]. Additionally, many individual metal species exhibit distinctively different environmental behaviors [12] PTM bioavailability, transport, and spatial distribution in soils are a complex phenomenon, affected by many factors such as total concentration [13, 14], $\mathrm{pH}[15]$, organic matter $[16]$, texture $[17,18]$, cation exchange capacity (CEC) [19], and redox reactions $[6,20]$. As physicochemical properties play an important role in the determination of the spatial distribution of metals in soil, evaluation of these parameters is necessary for environmental assessment.

In the United States, the chemical partitioning of PTMs in contaminated soils has been the topic of much research. $\mathrm{Ma}$ and Rao [21] investigated the chemical partitioning of PTMs in nine contaminated soils collected from various US locations and reported that the distribution of all of the metals except $\mathrm{Zn}$ in various chemical fractions were dependent on the respective total metal concentrations in the soils. Murray et al. [22] investigated the chemical speciation of bed sediment in an urban stream in Michigan and determined that metal concentrations in the reduced phase are strongly dependent on grain size, while there is little grain size control of residual metal concentrations. Additionally, analysis and interpretation of the spatial distribution patterns of PTMs have been used to evaluate the potential reactivity of PTMs [16, 23-25] and are widely used in soil pollution studies, providing qualitative evidence about trace element reactivity and indirect evidence of their bioavailability $[21,26]$. Few studies on the fractionation of PTMs around historical mines have been performed in the United States. In 2003, the aerial extent of PTM contamination in Montana related to long-term copper smelting was investigated by Burt et al. [24], in which trace element concentrations were found to have limited mobility and were related to distance and direction from source, topography, and soil physicochemical properties. In Colorado, the contamination of $\mathrm{Zn}$ and $\mathrm{Cd}$ as a result of historical underground mining of silver and base metals was examined by Burt et al. [25], who found that soil PTMs showed significant short-range spatial variability within $100 \mathrm{~s}$ of meters downstream of the mining district. These two studies demonstrate the need to (1) examine both physical and chemical properties of soil as drivers for PTM spatial distribution and (2) employ a fine spatial resolution sampling design to capture short-range spatial variability. The objectives of this research are therefore to (1) estimate host soil physical properties (texture, moisture content, and bulk density), chemical properties (cation exchange capacity (CEC), $\mathrm{pH}$, total organic carbon (TOC)), and PTM (Cu, $\mathrm{Mn}, \mathrm{Zn}, \mathrm{Pb}$, and $\mathrm{Cd}$ ) concentrations and (2) determine the spatial distribution of these contaminants in relation to soil properties in the vicinity of an abandoned mine complex.

1.1. Study Area. Tennessee's great abundance and variety of mineral deposits within sedimentary, metasedimentary, metamorphic, igneous, and unconsolidated country rock led to a thriving metallic mineral industry dating back to the $18^{\text {th }}$ century. Mineral production in Tennessee has included limonite, magnetite, hematite, gold, silver, copper, zinc, lead, and manganese [27]. Bumpus Cove helped establish the region's long history of iron, lead, zinc, and manganese mining [28].

Bumpus Cove is located in the southwest corner of Washington County and the northeast corner of Unicoi County, TN (Figure 1(a)) within the Unaka physiographic province, a subrange of the Appalachian Mountains. At nearly $3.2 \mathrm{~km}$ wide, the cove extends approximately $6.5 \mathrm{~km}$ to the northeast and is situated between two subparallel mountains: Rich Mountain $(\sim 1,035 \mathrm{~m})$ to the southeast and Embreeville Mountain ( $~ 885 \mathrm{~m})$ to the northwest [28]. In and around the cove, a conformable sequence of Paleozoic lithologies is preserved as a syncline. The valley floor and axis of the syncline lie within the Cambrian Shady Dolomite, which is well jointed and often considerably fractured and brecciated due to regional thrusting. The older, more resistant Cambrian Chilhowee Group sandstones underlie the ridges surrounding the cove [28]. The Chilhowee Group is also heavily thrust faulted and is composed of arkosic to arenitic sandstones interbedded with minor amounts of shales and conglomerates [29]. Bumpus Cove contains extensive deposits of iron, zinc, lead, and manganese ores. Zinc, lead, and iron sulfides reside within the Shady Dolomite, while the oxidized deposits of zinc, lead, iron, and manganese occur in the residual clay, emplaced through weathering processes [28].

The Bumpus Cove Creek watershed encompasses an area of about $19.5 \mathrm{~km}^{2}$ and drains northeastward into the larger Nolichucky Watershed (HUC 06010108). High annual rainfall, typical of the southeastern United States, can expedite transport of metals from topsoil to subsoil. Bumpus Cove has a humid, temperate climate (Köppen climate classification $\mathrm{Cfa}$ ) that experiences most of its rainfall in the summer months. Unicoi County experiences an average annual temperature of $14^{\circ} \mathrm{C}\left(57^{\circ} \mathrm{F}\right)$ and an average annual precipitation of $104 \mathrm{~cm}$ (41 in) [30]. The study area occupies $0.67 \mathrm{~km}^{2}$ and is bounded to the northeast by property lines; to the east and southeast by the $640 \mathrm{~m}$ topographic contour; to the south and southwest by the $670 \mathrm{~m}$ contour; and to the west and northwest by the $730 \mathrm{~m}$ contour. Within the study area, Bumpus Cove Creek flows north to northeast.

The mining history of a total of 47 mines in the cove extends from the Revolutionary War period to the early 1950s, when commercial activity was discontinued due to 


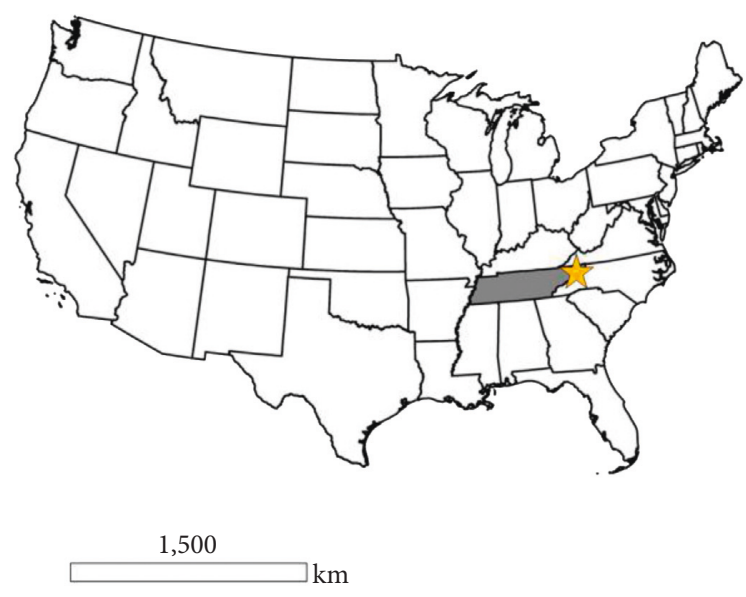

Study area

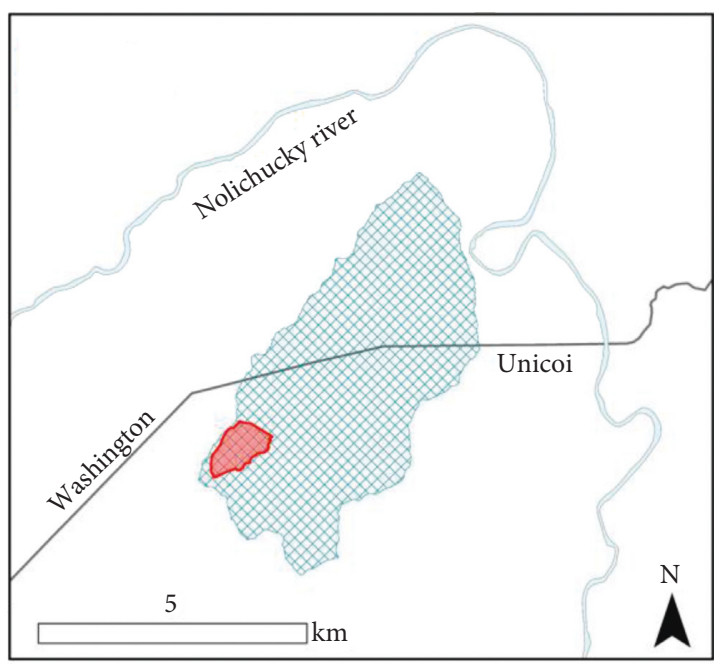

Study area

Bumpus cove

Watershed

(a)

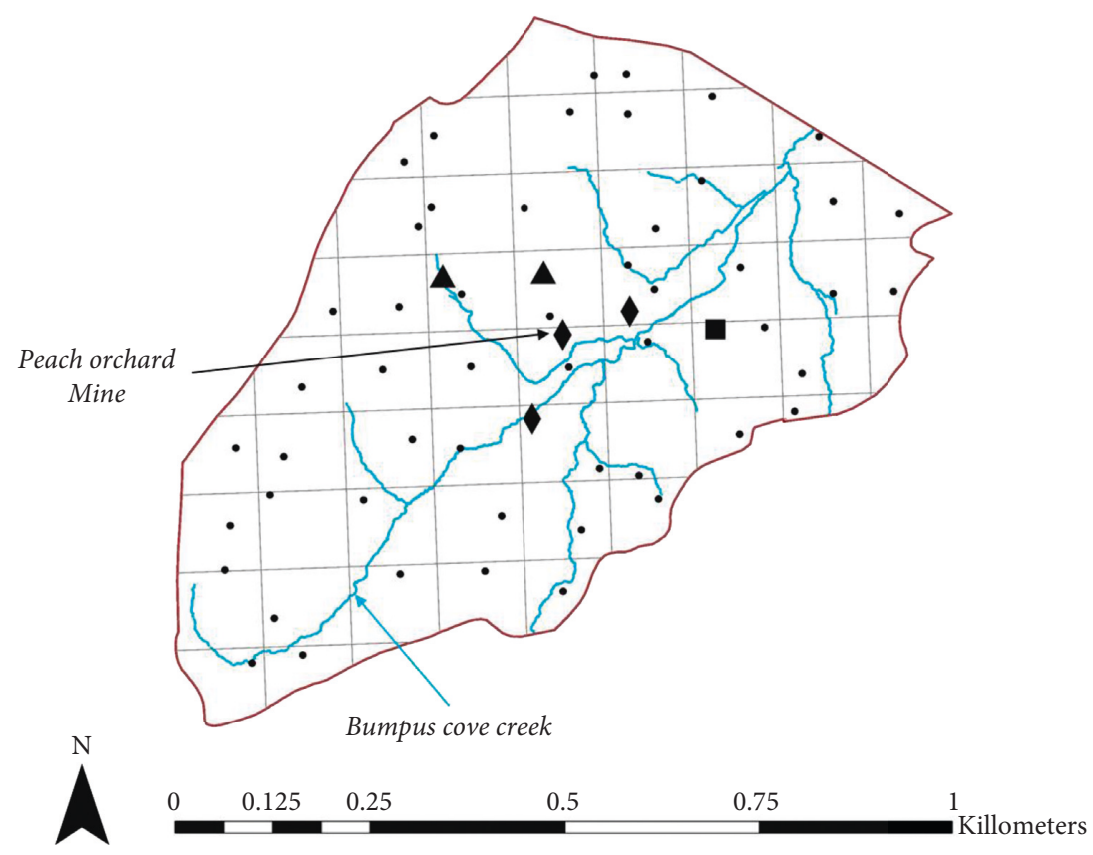

USGS Abandoned mines

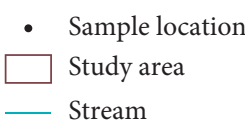

$\Delta \mathrm{Mn}$

口 $\mathrm{Zn}$

$\checkmark \mathrm{Zn}, \mathrm{pb}$

(b)

FIgURE 1: (a) Location of the study area $\left(0.67 \mathrm{~km}^{2}\right)$ in the southwest corner of the Bumpus Cove watershed $\left(\sim 19.5 \mathrm{~km}^{2}\right)$, Washington and Unicoi counties, Tennessee, and (b) study area sample and mine locations relative to Bumpus Cove Creek.

loss of government subsidies [31]. The abandoned Peach Orchard Mine, located in the southwest end of the cove on the northwest side of Bumpus Cove Creek, was the most productive zinc and lead mine in the history of the cove. The Peach Orchard Mine operated between 1916-1926 and
1931-1943 and was the chief producer of lead and zinc in the United States during this time [28]. Five additional abandoned mines operated within the same timeframe and exist in the immediate vicinity of the Peach Orchard Mine (Figure 1(b)). 


\section{Materials and Methods}

A simplified flow chart of methods used in this study is presented in Figure 2.

2.1. Sampling Procedure. A total of 52 soil samples were collected within the study area in 2016. Sampling point locations were semirandomly selected by dividing the study area into a grid composed of 51 rectangular cells $(\sim 130 \mathrm{~m} \times \sim 115 \mathrm{~m})$ using the fishnet tool in ArcGIS 10.1 [32]. At least one soil sample was taken randomly within each cell using individual plastic soil core samplers after removal of the thick humus layer by a steel trowel. At each sampling point, soil core samples for chemical analyses were collected directly in sterilized PVC soil tubes, sealed on-site in labeled plastic bags and transported to the laboratory in a cooler. An additional $500 \mathrm{~g}$ of bulk soil was collected at each sampling site to be used for physical analyses. All samples were obtained from depths of 0 to $15 \mathrm{~cm}$.

2.2. Lab Methods. Lab methods included physical (grain size distribution (GSD), moisture content, bulk density, and porosity) and chemical (flame atomic absorption spectrometry (FAAS), pH, TOC, and CEC) analyses. All data are reported on a dry weight basis.

Moisture content and bulk density for each sample was evaluated according to the American Society for Testing and Materials (ASTM) D2216 and D7263, respectively. To determine particle size fractions of the collected soil, GSD was performed using sieve and hydrometer methods according to ASTM D422. Each bulk sediment sample was sieved and plotted on a GSD curve using the size fractions: 4.75, 2, 0.6, $0.212,0.15,0.106$, and $0.075 \mathrm{~mm}$. The hydrometer method was used to assess the finer fractions $(<0.075 \mathrm{~mm})$. Soil texture was determined using the Unified Soil Classification System (USCS).

Soil chemical analyses included pH $\left(1: 1\right.$ in $\mathrm{H}_{2} \mathrm{O}$ [33]), cation exchange capacity (CEC by summation [34]), and total organic content (TOC loss on ignition at $360^{\circ} \mathrm{C} \mathrm{[35]).}$ PTM concentrations for $\mathrm{Mn}, \mathrm{Zn}, \mathrm{Pb}, \mathrm{Cu}$, and $\mathrm{Cd}$ were determined by flame atomic absorption spectrometry (FAAS) analysis (Varian SpectrAA 220 FS). In accordance with EPA Method 3052, microwave-assisted acid digestion of the finer fractions was employed to break down the sample matrix and leave the analytes of interest in solution and ready for analysis. Calibration curves were prepared for each metal by running a series of concentrations of standard solutions, metal concentrations were analyzed, and all values were converted to $\mathrm{mg}$ of PTM per $\mathrm{kg}$ of soil ( $\mathrm{mg} / \mathrm{kg}$ or $\mathrm{ppm})$.

2.3. Data Analysis. Physical and chemical analyses data for each sample were assembled into a database using the Statistical Package for the Social Sciences [36]. Descriptive statistics, scatterplots, and Spearman's rho correlation coefficients were calculated for each variable; then, multicollinearity among the variables was assessed. Correlation coefficients were used to select explanatory variables for regression analysis. Spatial autocorrelation for each PTM was assessed using univariate local Moran's I in GeoDa 1.6 [37]. Explanatory (soil physicochemical properties) and response variables (PTM concentrations) are shown in Table 1. Ordinary kriging surfaces were created for explanatory variables using anisotropy to account for SW-NE trending drainage influence within the study area. Spatial weights were created for three distance thresholds (150, 200, and 300 meters) to better understand spatial relationships that exist among the variables. The lowest distance threshold $(150 \mathrm{~m})$ was the minimum distance between neighbors, as given by local Moran's I, and the two larger neighborhood sizes $(200$ and $300 \mathrm{~m}$ ) were selected to allow for expected spatial variability in metal concentrations at small distances as reported by Burt et al. [25]. The selection of an appropriate spatial regression model is dependent on PTM variability among sample sites, and thus, the model and size of the spatial neighborhood may differ for each metal. The spatial lag model assumes there is an underlying spatial process not captured in the data and models it with a new spatial variable $(\lambda)$ that is a function of estimates of the dependent variable at nearby locations. The spatial error model instead models the spatial variability as a spatially varying error term. For each of the three distance-based weights, three spatial models were developed: ordinary least squares (OLS), spatial lag (SLag), and spatial error (SError). For each metal, the best of the nine models was selected according to the highest $R^{2}$ and lowest Akaike Information Criterion (AIC) spatial diagnostics, as well as by assessing spatial autocorrelation in the residuals.

\section{Results and Discussion}

3.1. Soil Physicochemical Properties. Descriptive statistics and ordinary kriging maps for general soil characteristics of the abandoned mine complex are presented in Table 2 and Figure 3, respectively. Elevation (Figure 3(a)) in the study area ranged between $540 \mathrm{~m}$ and $770 \mathrm{~m}$ and was lowest in the drainage valleys and highest in the north, south, and southwest. The southeast-facing slope is much more rugged and is noticeably contoured by abandoned mining terraces at its center. GSD analysis showed that all samples were wellgraded sands ( $94.5 \%$ sand, $0.04 \%$ silt, and $0.01 \%$ clay) as defined by the USCS classification. Figure 4 shows the upper and lower bounds as a range in grain size within the sand textural class. The sand (Figure 3(b)) textural class comprised $88-99 \%$ of all soil samples and was highest along drainage pathways and lowest in the southwest. Silt (Figure 3(c)) had a much lower range of $1-11 \%$ and, as expected, showed the inverse spatial pattern of the sand textural class, with silt less predominant along drainage pathways and highest in the southwest. Clay (Figure 3(d)) had a maximum of only $3 \%$ but showed a decreasing trend from the northeast to southwest. Soil moisture content (Figure 3(e)) ranged from $8-53 \%$, had one outlier at $75 \%$, and generally increased towards the east-central region of the study area. Soil bulk density (Figure 3(f)) ranged from 1$2 \%$ and increased eastward across the study area. Soil pH (Figure $3(\mathrm{~g})$ ) varied from very acidic ( $\mathrm{pH}$ as low as 3.6) 


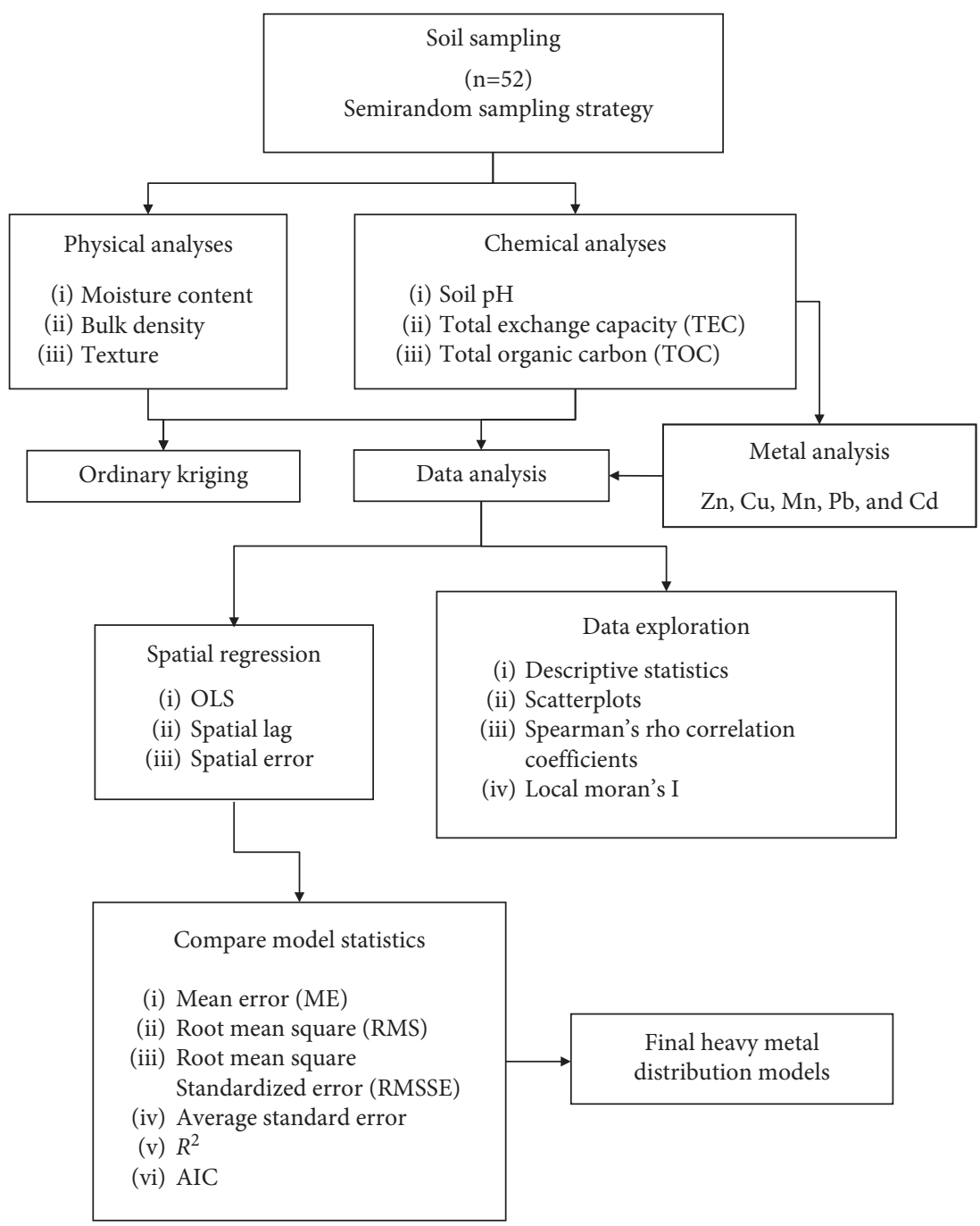

FIgure 2: Physical and chemical analyses of soil samples were used to develop spatial prediction models for PTM distribution.

TABLE 1: Explanatory and response variables.

\begin{tabular}{lc}
\hline Explanatory variables & Response variables \\
\hline $\begin{array}{l}\text { Physical properties (texture, moisture } \\
\text { content, and bulk density) }\end{array}$ & Metal concentrations \\
Chemical properties (CEC, $\mathrm{pH}$, and TOC) & $\mathrm{Cu}, \mathrm{Mn}, \mathrm{Zn}, \mathrm{Pb}$, and \\
\end{tabular}

around the northwest and southeast perimeters, to neutral (up to $\mathrm{pH}$ 7.6) from the southwest to the northeast, especially towards the central valley. The neutral $\mathrm{pH}$ trends parallel to the fold axis of the Shady Dolomite, which likely neutralizes soil acidity. CEC (Figure 3(h)) was variable throughout the study area with six outliers $(11-17 \mathrm{meq} /$ $100 \mathrm{~g}$ ), but the majority ranged from 2 to $8 \mathrm{meq} / 100 \mathrm{~g}$ and generally increased towards the center of the study area. Most of the soils had TOC (Figure 3(i)) ranging from only $3-18 \%$, with an outlier reaching $32 \%$. In the study area, TOC gradually decreased from northwest to southeast. Overall low CEC and TOC in the valley are typical for a disturbed, un-reclaimed mine area.
3.2. PTMs and Soil Properties. Concentrations for $\mathrm{Zn}, \mathrm{Mn}$, and $\mathrm{Pb}$ show significant variability between sample sites (ranges of $12-1,354 \mathrm{mg} / \mathrm{kg} \mathrm{Zn,} \mathrm{6-2,574} \mathrm{mg/kg} \mathrm{Mn,} \mathrm{and}$ $33-2,271 \mathrm{mg} / \mathrm{kg} \mathrm{Pb}) . \mathrm{Cu}$ and $\mathrm{Cd}$ were much less variable, with ranges of $1-65 \mathrm{mg} / \mathrm{kg}$ and $7-40 \mathrm{mg} / \mathrm{kg}$, respectively. Of the measured PTMs, in general, only $\mathrm{Pb}$ exceeded EPA permissible limits $(420 \mathrm{mg} / \mathrm{kg})$ in soils [38]. Spearman's rho correlations between soil properties and PTM concentrations are summarized in Table 3. Only significant correlations are shown. Amongst soil properties, moisture content, bulk density, $\mathrm{pH}$, and CEC are positively correlated with sand and negatively correlated with silt. Sand is negatively correlated with silt and clay textural classes, whereas clay is positively associated with silt. TOC is positively correlated with CEC and negatively correlated with bulk density. All metals $(\mathrm{Zn}, \mathrm{Mn}, \mathrm{Cu}, \mathrm{Pb}$, and $\mathrm{Cd})$ are strongly and positively correlated with each other, except $\mathrm{Mn}$ and $\mathrm{Cd}$, which show no correlation. All metals also show strong positive association with $\mathrm{pH}$, but only $\mathrm{Cu}$ and $\mathrm{Cd}$ show a positive association with moisture content. Each metal is also positively 
TABle 2: Descriptive statistics for soil physical and chemical properties and metal concentrations.

\begin{tabular}{|c|c|c|c|c|c|c|}
\hline Variables & Min & $\operatorname{Max}$ & Mean & Standard deviation & Skewness & Kurtosis \\
\hline \multicolumn{7}{|l|}{ Soil properties } \\
\hline Moisture content (\%) & 8.29 & 75.21 & 24.59 & 13.2 & 1.4 & 3.1 \\
\hline $\mathrm{BD}\left(\mathrm{g} / \mathrm{cm}^{3}\right)$ & 0.79 & 1.79 & 1.25 & 0.2 & 0.2 & -0.07 \\
\hline $\mathrm{pH}$ & 3.60 & 7.60 & 4.89 & 0.8 & 1.3 & 2.2 \\
\hline CEC (meq/100 g) & 1.52 & 16.58 & 4.83 & 3.5 & 1.8 & 2.9 \\
\hline TOC (\%) & 3.20 & 31.46 & 8.61 & 4.7 & 2.6 & 10.6 \\
\hline Sand (\%) & 87.65 & 98.83 & 94.50 & 0.03 & -0.5 & -0.8 \\
\hline Silt (\%) & 0.82 & 10.73 & 4.34 & 0.03 & 0.6 & -0.8 \\
\hline Clay (\%) & 0.00 & 2.60 & 1.14 & 0.01 & 0.3 & -0.2 \\
\hline \multicolumn{7}{|l|}{ Metal concentration } \\
\hline $\mathrm{Zn}(\mathrm{mg} / \mathrm{kg})$ & 11.80 & 1354.16 & 302.52 & 402.7 & 1.7 & 1.6 \\
\hline $\mathrm{Cu}(\mathrm{mg} / \mathrm{kg})$ & 1.14 & 64.67 & 13.96 & 13.2 & 2.3 & 5.9 \\
\hline $\mathrm{Mn}(\mathrm{mg} / \mathrm{kg})$ & 6.29 & 2574.93 & 344.49 & 652.2 & 2.4 & 4.9 \\
\hline $\mathrm{Pb}(\mathrm{mg} / \mathrm{kg})$ & 33.43 & 2271.43 & 326.69 & 529.6 & 2.7 & 6.4 \\
\hline $\mathrm{Cd}(\mathrm{mg} / \mathrm{kg})$ & 7.14 & 40.00 & 11.86 & 5.1 & 3.6 & 17.8 \\
\hline
\end{tabular}

$\mathrm{BD}$, bulk density; $\mathrm{CEC}$, cation exchange capacity; TOC, total organic carbon.

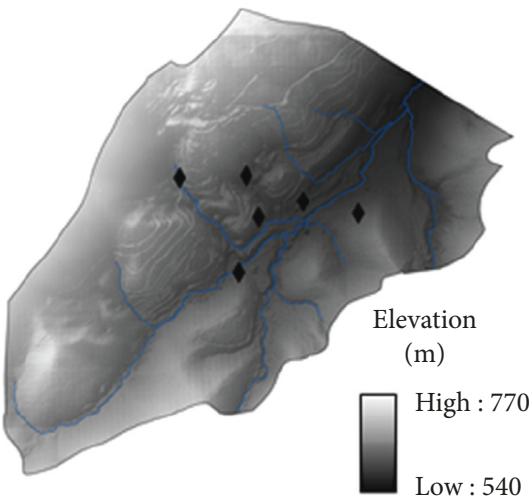

(a)

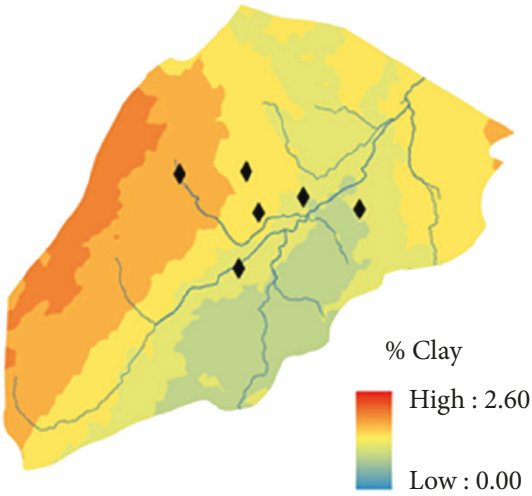

(d)

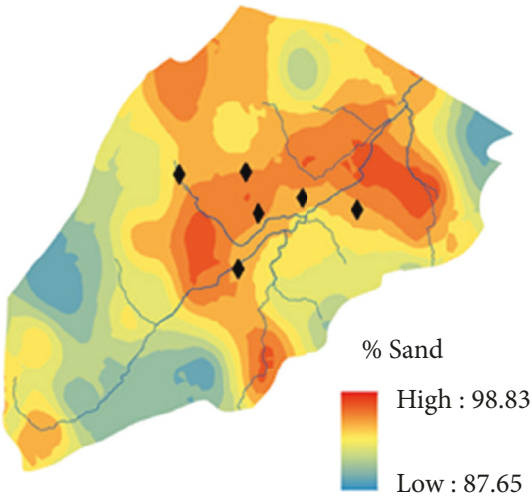

(b)

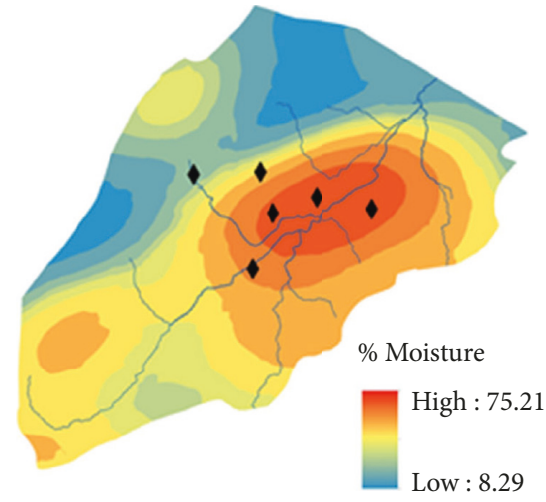

(e)

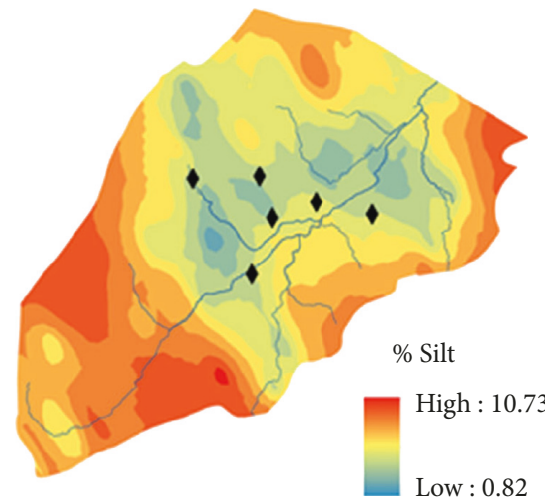

(c)

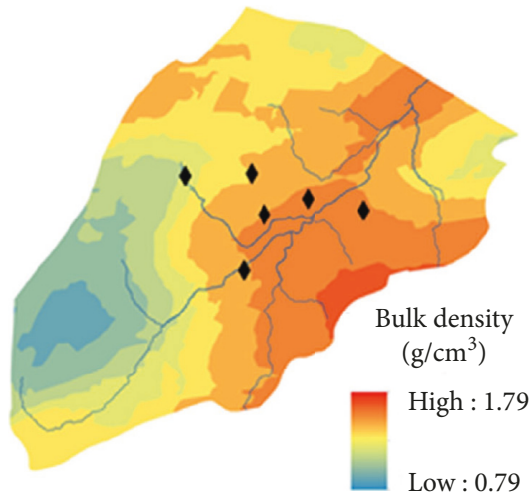

(f)

FIgure 3: Continued. 


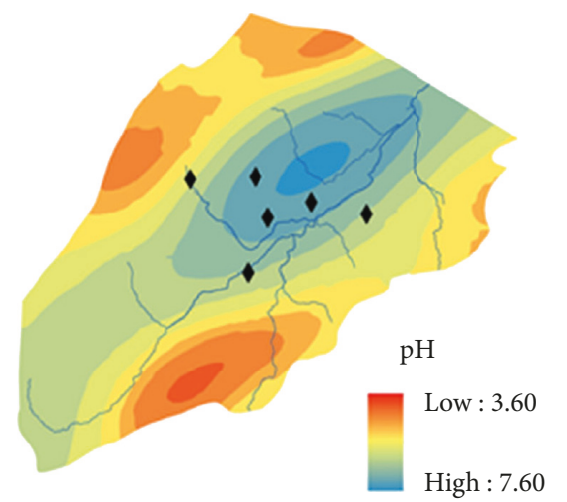

(g)

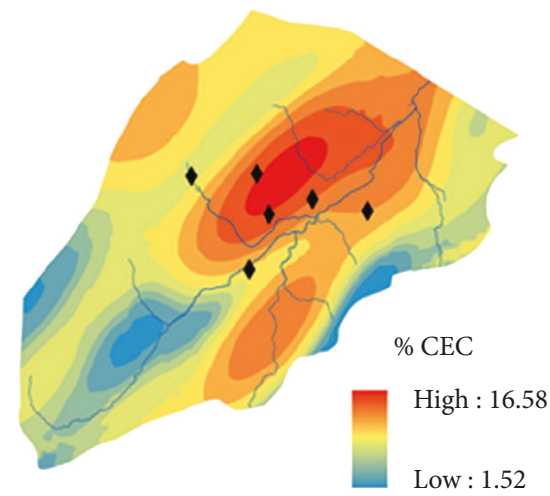

(h)

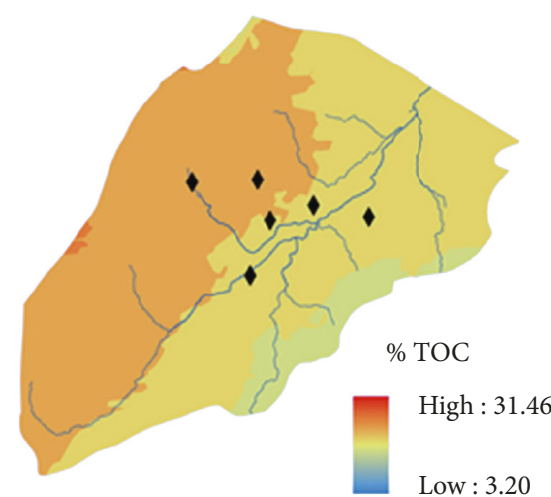

(i)

FIGURE 3: Ordinary kriging interpolation maps of soil physical and chemical properties: (a) elevation; (b-d) grain size distribution of sand, silt, and clay; (e) moisture content; (f) bulk density (g) pH; (h) cation exchange capacity (CEC); and (i) total organic carbon (TOC).

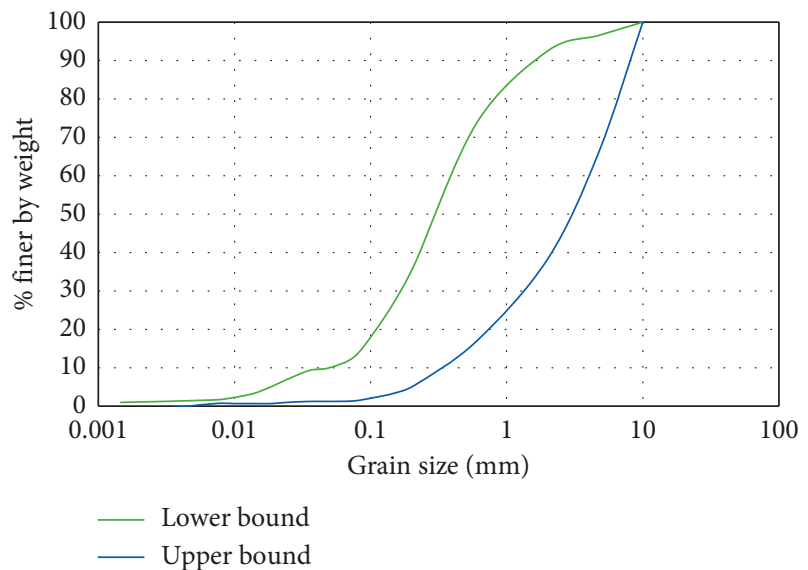

Figure 4: Grain size distribution of upper and lower bounds, classified according to the USCS.

associated with sand and strongly negatively correlated with silt, except $\mathrm{Zn}$, which is not correlated with a textural class.

Soil physical properties play an important role in PTM storage and spatial distribution. Strong positive correlation is generally expected between metals and decreasing particle size fractions because smaller particles have a greater specific surface area and a negative charge which increases the capacity for metal retention $[7,15,39-41]$. This was not evident in the present study; however, larger grain sizes may better document metal content from anthropogenic sources as a result of their limited transport and longer residence time at a given site [42]. Surface soils of the present study exhibited a well-graded sand textural class which may follow such a pattern because all metals except $\mathrm{Zn}$ were significantly and positively correlated with $\%$ sand and significantly and negatively correlated with $\%$ silt. Additionally, as expected in the study area, turbulent stream in hilly landscape deposited sands as bed load materials that eroded from surrounding slopes of Chilhowee Group sandstones. Correlations between PTM concentrations and soil moisture content obtained in this study agree with those of Sharma and Raju [43], who indicated that metal retention increases with moisture content. This is probably attributed to enhanced hydrolysis of metals, especially under acidic conditions; however, this trend was only apparent for $\mathrm{Cu}$ and $\mathrm{Cd}$ concentrations. Bulk density was not shown to influence PTM concentrations in Bumpus Cove. Soil bulk density greatly depends on mineral composition and degree of compaction, and although this can influence PTM distribution, soil bulk density is rarely used to determine total metal content [44].

According to Ghosh and Singh [45] and Zeng et al. [46], $\mathrm{pH}$ has the greatest effect of any single factor on the solubility or retention of PTMs in soils such that increasing solubility is associated with increasing soil acidity $[5,15]$. The United States Department of Agriculture (USDA) and Natural Resources Conservation Service (NRCS) [38] recommend increasing soil $\mathrm{pH}$ to 6.5 or higher to help reduce mobilization and enhance accumulation, thus the potential for adverse effects of metals on transport to surface or ground water. Soils in the Bumpus Cove study area are relatively acidic to neutral, ranging between 3.6 and $7.6 \mathrm{pH}$. Soil acidity was higher in the sandstone ridges and slopes and close to neutral in the valley comprising dolomitic bedrock that helps neutralize the soil acidity. Soil $\mathrm{pH}$ was significantly and positively correlated with all metals, perhaps due to increased metal concentration in near-neutral $\mathrm{pH}$ environment. High CEC has been reported to influence PTM retention [45, 47, 48]. Navas and Machin [47] reported that CEC has shown significant and positive correlations with $\mathrm{Zn}, \mathrm{Mn}$, and $\mathrm{Pb}$, but no significant correlations with $\mathrm{Cu}$ and Cd. For soils of the Bumpus Cove study area, CEC was retained as a covariate in spatial regression models for both $\mathrm{Zn}$ and $\mathrm{Pb}$. In agreement with Navas and Machin [47], the relationship between $\mathrm{Pb}$ and $\mathrm{CEC}$ was positive; however, in contrast to their results, the relationship between $\mathrm{Zn}$ and CEC was negative in our model. TOC has been reported in previous works to be one of the significant soil parameters influencing PTM concentration [49]. The strong affinity of $\mathrm{Cu}$ for TOC observed by Imperato et al. [50] was not recognized as an overall major factor in the PTM distribution at Bumpus Cove. Absence of correlation of CEC and TOC with 
TABLE 3: Spearman's rho correlation coefficients for soil properties and PTM concentrations $(n=52)$. Significant correlations are marked with ${ }^{*}(p<0.05)$ or ${ }^{* *}(p<0.01)$.

\begin{tabular}{|c|c|c|c|c|c|c|c|c|c|c|}
\hline Variables & $\begin{array}{c}\text { Moisture } \\
\text { content (\%) }\end{array}$ & $\mathrm{BD}\left(\mathrm{g} / \mathrm{cm}^{3}\right)$ & $\mathrm{pH}$ & $\begin{array}{c}\text { CEC } \\
(\mathrm{meq} / 100 \mathrm{~g})\end{array}$ & Sand (\%) & Silt (\%) & $\mathrm{Zn}(\mathrm{mg} / \mathrm{kg})$ & $\mathrm{Mn}(\mathrm{mg} / \mathrm{kg})$ & $\mathrm{Cu}(\mathrm{mg} / \mathrm{kg})$ & $\begin{array}{c}\mathrm{Pb} \\
(\mathrm{mg} / \mathrm{kg})\end{array}$ \\
\hline \multicolumn{11}{|c|}{ Soil properties } \\
\hline $\mathrm{BD}$ & $0.309^{*}$ & 1 & & & & & & & & \\
\hline $\mathrm{pH}$ & $0.364^{* *}$ & - & 1 & & & & & & & \\
\hline $\mathrm{CEC}$ & - & - & - & 1 & & & & & & \\
\hline TOC & $0.278^{*}$ & $-0.571^{* *}$ & - & $0.341^{*}$ & & & & & & \\
\hline Sand & $0.457^{* *}$ & $0.375^{* *}$ & $0.488^{* *}$ & $0.409^{* *}$ & 1 & & & & & \\
\hline Silt & $-0.459^{* *}$ & $-0.362^{* *}$ & $-0.531^{* *}$ & $-0.450^{* *}$ & $-0.979^{* *}$ & 1 & & & & \\
\hline Clay & - & - & - & - & $-0.640^{* *}$ & $0.515^{* *}$ & & & & \\
\hline \multicolumn{11}{|c|}{ Metal concentrations } \\
\hline $\mathrm{Zn}$ & - & - & $0.445^{* *}$ & - & - & - & 1 & & & \\
\hline $\mathrm{Mn}$ & - & - & $0.400^{* *}$ & - & $0.343^{*}$ & $-0.388^{* *}$ & $0.430^{* *}$ & 1 & & \\
\hline $\mathrm{Cu}$ & $0.319^{*}$ & - & $0.543^{* *}$ & - & $0.556^{* *}$ & $-0.593^{* *}$ & $0.435^{* *}$ & $0.521^{* *}$ & 1 & \\
\hline $\mathrm{Pb}$ & - & - & $0.546^{* *}$ & - & $0.442^{* *}$ & $-0.471^{* *}$ & $0.415^{* *}$ & $0.337^{*}$ & $0.750^{* *}$ & 1 \\
\hline $\mathrm{Cd}$ & $0.296^{*}$ & - & $0.523^{* *}$ & - & $0.318^{*}$ & $-0.379^{* *}$ & $0.379^{* *}$ & - & $0.557^{* *}$ & $0.504^{* *}$ \\
\hline
\end{tabular}

TABLE 4: Spatial multivariate regression results.

\begin{tabular}{|c|c|c|c|c|c|c|}
\hline \multicolumn{2}{|c|}{ Diagnostic } & $\mathrm{Zn}$ & $\mathrm{Mn}$ & $\mathrm{Cu}$ & $\mathrm{Pb}$ & $\mathrm{Cd}$ \\
\hline \multicolumn{2}{|c|}{ Distance threshold (m) } & 150 & 300 & 200 & 150 & 150 \\
\hline \multicolumn{2}{|c|}{ Best spatial model } & Spatial error & Spatial error & Spatial error & Spatial error & Spatial lag \\
\hline \multirow{4}{*}{$R^{2}$} & OLS & 0.371 & 0.162 & 0.366 & 0.515 & 0.558 \\
\hline & SLag & 0.384 & 0.186 & 0.369 & 0.615 & 0.617 \\
\hline & SError & 0.400 & 0.212 & 0.369 & 0.694 & 0.587 \\
\hline & OLS & 762.255 & 827.317 & 406.895 & 779.265 & 290.25 \\
\hline \multirow[t]{3}{*}{ AIC } & SLag & 763.487 & 828.315 & 408.711 & 772.458 & 286.875 \\
\hline & SError & 760.706 & 825.638 & 406.729 & 762.513 & 288.248 \\
\hline & Soil properties retained & $\begin{array}{l}\mathrm{pH}(+) \\
\mathrm{CEC}(-)\end{array}$ & $\begin{array}{c}\text { Moisture content }(-) \\
\% \text { silt }(-)\end{array}$ & $\begin{array}{c}\% \text { sand }(-) \\
\% \text { silt }(-) \\
\text { BD }(-)\end{array}$ & $\begin{array}{c}\mathrm{pH}(+) \\
\mathrm{CEC}(+) \\
\lambda(-)\end{array}$ & $\begin{array}{c}\mathrm{pH}(+) \\
\% \text { sand }(-) \\
\% \text { silt }(-) \\
W y(-)\end{array}$ \\
\hline
\end{tabular}

$\lambda$ is a spatial autoregressive error term; $W y$ is a spatially lagged dependent variable; and $(+)$ and $(-)$ indicate the sign of the coefficient.

PTMs are evident from low clay and organic contents in the un-reclaimed and disturbed mine area in Bumpass Cove.

\subsection{Spatial Models to Predict PTM Concentration.} Spatially weighted multivariate regression models developed for PTMs using soil physicochemical properties (Table 4) produced improved results over OLS regression models. Here, $\lambda$ is a spatial autoregressive error parameter that accounts for spatial autocorrelation in the error term and $W y$ is a spatially lagged dependent variable that incorporates the neighboring values into the prediction for each location.

For $\mathrm{Zn}$, the spatial error model $\left(R^{2}=0.40\right)$ was the best model using the lowest distance threshold $(150 \mathrm{~m})$. The best model for Mn was the spatial error model $\left(R^{2}=0.21\right)$ using the highest distance threshold $(300 \mathrm{~m})$, and the best model for $\mathrm{Cu}$ was the spatial error model $\left(R^{2}=0.37\right)$ with the middle distance threshold $(200 \mathrm{~m})$. The best models for $\mathrm{Pb}$ and $\mathrm{Cd}$ were the spatial error $\left(R^{2}=0.69\right)$ and spatial lag $\left(R^{2}=0.62\right)$ models, respectively, both using the lowest distance threshold $(150 \mathrm{~m})$. Regression models underpredicted at high values for all metals; residuals showed no significant spatial autocorrelation (Figure 5).

Multivariate regression analysis revealed soil properties associated with each metal. From examination of standardized coefficients (not presented here, but available in Supplementary Materials (available here)), $\mathrm{Pb}$ was more sensitive to $\mathrm{pH}$ than $\mathrm{CEC}$, while $\mathrm{Zn}$ was equally sensitive to both. Similarly, $\mathrm{Cd}$ was more sensitive to $\mathrm{pH}$ than soil texture. $\mathrm{Cu}$ was sensitive to changes in bulk density and soil texture equally, as was Mn for moisture content and texture. As expected, multicollinearity was identified between sand and silt using tolerance and variance inflation factor (VIF) diagnostics.

Of the measured PTMs, only Pb concentrations exceeded EPA permissible $420 \mathrm{mg} / \mathrm{kg}$ limit in soils and did so by over a factor of 5 [38]. While $\mathrm{Pb}$ was a major ore in the Peach Orchard and two other mines in the cove, elevated $\mathrm{Pb}$ concentration could also be related to presence of $\mathrm{Pb}$ shotgun pellets from active game hunting at the site. Weathering of $\mathrm{Pb}$ bullets are of common environmental concern, as $\mathrm{Pb}$ in bullets coverts to compounds like lead 
$\Lambda$
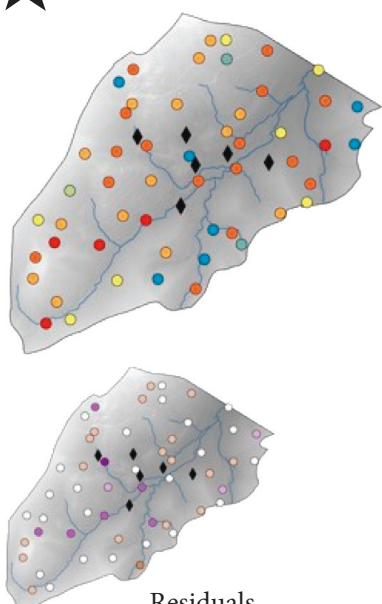

Residuals

$\mathrm{N}$

$\Lambda$

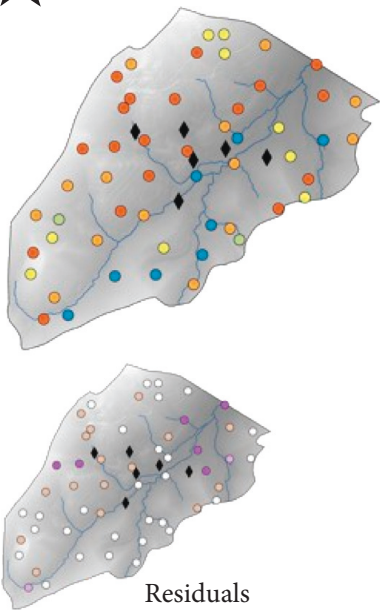

Predicted (mg/kg) Residuals (std. dev.)

648 to 1354

378 to $648 \quad-2.5$ to -1.5

198 to $378 \quad-1.5$ to -0.5

96 to $198 \bigcirc-0.5$ to -0.5

$\bigcirc 5$ to $96 \quad 0.5$ to -1.5

23 to 55

0 to 23

(a)

Predicted $(\mathrm{mg} / \mathrm{kg})$ Residuals (std. dev.)

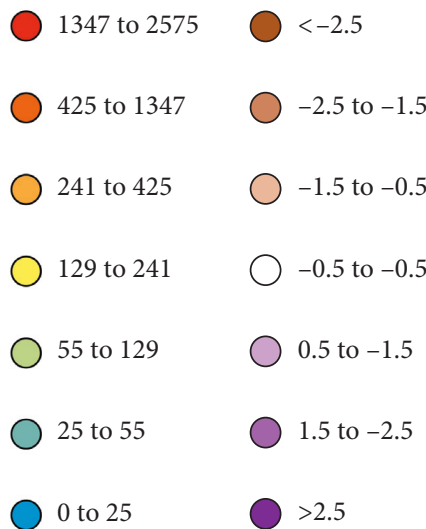

(c)
$\stackrel{\mathrm{N}}{\Lambda}$

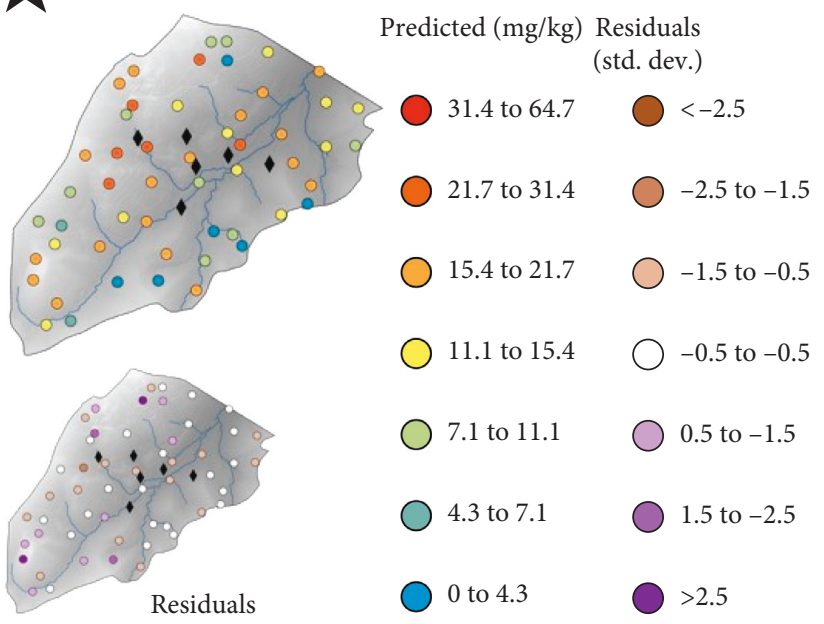

(b)

$\stackrel{N}{\Lambda}$
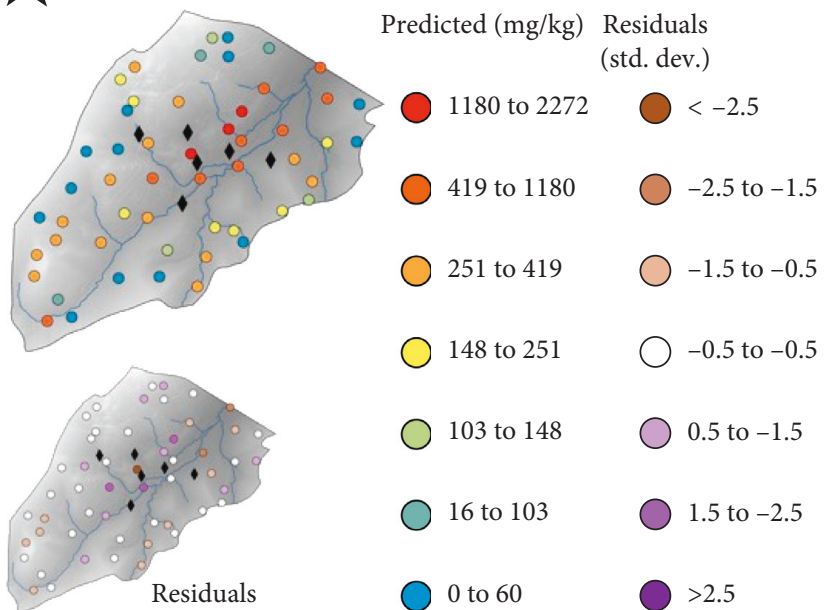

103 to $148 \quad 0.5$ to -1.5

16 to $103 \bigcirc 1.5$ to -2.5

0 to 60

(d)

Predicted (mg/kg) Residuals

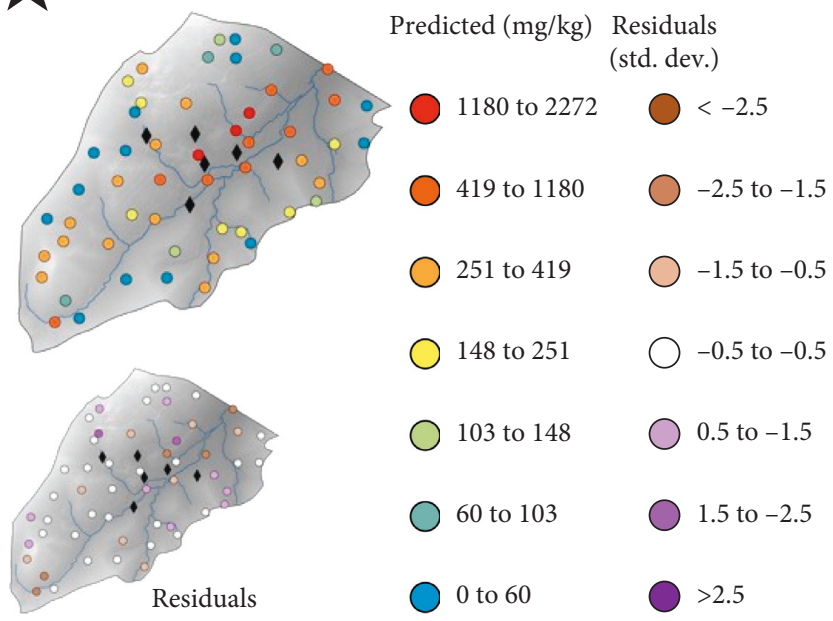

(e)

FIGURE 5: Spatial regression model results showing predicted concentrations and residuals for (a) zinc, (b) copper, (c) manganese, (d) lead, and (e) cadmium. 
oxides and carbonates and stays in soil for 100-300 years [51-53]. At $\mathrm{pH}>6.0$, in soils with high calcite, iron, and phosphorus content, $\mathrm{Pb}$ becomes immobile and stays trapped in soil. In the cove, $\mathrm{Zn}$ concentrations greatly exceeded the common $10-300 \mathrm{mg} / \mathrm{kg}$ range in soils by a factor of $\sim 4$. $\mathrm{Zn}$ was also concentrated upgradient of the mines, possibly due to the presence of tailings and slag or because of bioaccumulation. Unmapped/unrecognized mine shafts may have also affected $\mathrm{Zn}$ concentrations, especially since the locations of the USGS-abandoned mine locations are approximate. $\mathrm{Mn}, \mathrm{Pb}$, and $\mathrm{Cd}$ were concentrated near the drainage pathways, with abandoned mine locations as general source points. $\mathrm{Cu}$ had no ore sources in the study area, and the best regression model retained the lowest distance threshold, indicating that $\mathrm{Cu}$ is spatially dependent at short distances of $150 \mathrm{~m}$, but the spatial dependence is not as strong for larger neighborhoods of 200 and $300 \mathrm{~m}$. Both models for $\mathrm{Cu}$ showed a general northwest to southeast decrease, and the metal is likely originating from the northwest Chilhowee Group Sandstone ridge.

Due to the extremely heterogenous nature of soils in general, it is impossible to capture all features of the study area without the employment of some approximations [54]. Soil properties collectively govern the binding capacity of PTMs to soil, but they alone do not determine the geographical distribution of PTMs, as shown in the present study. Future works may include further analysis of individual PTM chemical forms using X-ray spectroscopy, isotope ratios to track the source, and additional sampling of groundwater, surface water, and vegetation. Additionally, future works may consider the effects of bioaccumulation on PTM distribution, which was not accounted for in the present study but may help explain the close spatial variability among metals. The results of this study can initiate government remediation action, as well as provide a reference for selection of the best remediation strategies. In situ remediation technologies focus on increasing the binding potential to soil particles, whereas ex situ remediation aims to extract or separate metals from sediments. Ex situ remediation methods are costly and most often applied to heavily polluted soils; therefore, in situ remediation technologies (i.e., sand-capping streams and soil amendments) are suggested for the soils at Bumpus Cove, TN. Since phytoremediation does not apply to $\mathrm{Pb}$, it is not a recommended means of remediation.

\section{Conclusions}

Abandoned and un-reclaimed metalliferous mines of Bumpus Cove, TN, have led to accumulation of PTMs in the surrounding soils over the last $65+$ years. PTM concentrations of $\mathrm{Zn}, \mathrm{Mn}, \mathrm{Cu}, \mathrm{Pb}$, and $\mathrm{Cd}$ from 52 soil samples were determined by FAAS. Of the measured PTMs, only Pb exceeded EPA regulatory limits in soils. Spatially weighted multivariate regression models developed for PTMs using soil physicochemical properties produced improved results over OLS regression models. The best model was for $\mathrm{Pb}$, where $69 \%$ of variability in $\mathrm{Pb}$ concentrations was explained by $\mathrm{pH}, \mathrm{CEC}$, and a spatially varying error term $\lambda\left(R^{2}=0.69\right)$.
Of the explanatory variables, $\mathrm{pH}$ was the most highly correlated with all metals. Overall, the spatial distribution of PTM concentrations indicates the abandoned mines as source points for $\mathrm{Zn}, \mathrm{Mn}, \mathrm{Pb}$, and $\mathrm{Cd}$ because the highest concentrations were found in the mining vicinity. This study provides data-driven explanations for the spatial distribution of PTMs in Bumpus Cove soils and can provide a reference for state and local entities responsible for PTM monitoring in Bumpus Cove, TN.

\section{Data Availability}

The data used to support the findings of this study are available from the corresponding author upon request.

\section{Conflicts of Interest}

The authors declares that there are no conflicts of interest regarding the publication of this paper.

\section{Acknowledgments}

The authors thank Brian Evanshen and Dr. Phil Scheuerman for use of the East Tennessee State University Department of Environmental Health Sciences laboratory and direction with laboratory safety and procedures. The authors also acknowledge Mr. Rick Turner and the Tennessee Wildlife Resources Agency (TWRA) for permitting access to the study area and for showing interest in this work. Thanks are due to Jamie Kincheloe, Dr. Mick Whitelaw, Alex McClain, Macon Magno, Samuel Hauser, and Isaac Shockley for assisting in data collection and processing. This project received funding from the Association of Environmental and Engineering Geologists (AEG) and the East Tennessee State University Honors College Office of Undergraduate Research \& Creative Activities.

\section{Supplementary Materials}

Tables containing regression coefficients and standardized coefficients will be made available in the supplementary material. (Supplementary Materials)

\section{References}

[1] B. J. Alloway, Heavy Metals in Soils, Springer Science and Business Media, Berlin, Germany, 1995.

[2] R. J. Reeder, M. A. A. Schoonen, and A. Lanzirotti, "Metal speciation and its role in bioaccessibility and bioavailability," Medical Mineralogy and Geochemistry, vol. 64, no. 1, pp. 59-113, 2006.

[3] G. M. Pierzynski, G. F. Vance, and J. T. Sims, Soils and Environmental Quality, CRC Press, Boca Raton, FL, USA, 2005.

[4] R. D. Roberts and M. S. Johnson, "Dispersal of heavy metals from abandoned mine workings and their transference through terrestrial food chains," Environmental Pollution (1970), vol. 16, no. 4, pp. 293-310, 1978.

[5] R. H. Dowdy and V. V. Volk, "Movement of heavy metals in soils," in Chemical Mobility and Reactivity in Soil Systems, 
pp. 227-240, Soil Science Society of America: American Society of Agronomy, Madison, MI, USA, 1983.

[6] C. K. Jain, "Metal fractionation study on bed sediments of River Yamuna, India," Water Research, vol. 38, no. 3, pp. 569-578, 2004.

[7] W. Salomons and U. Förstner, "Trace metal analysis on polluted sediments," Environmental Technology Letters, vol. 1, no. 11, pp. 506-517, 1980.

[8] Z. Li and L. M. Shuman, "Heavy metal movement in metalcontaminated soil profiles," Soil Science, vol. 161, no. 10, pp. 656-666, 1996.

[9] A. C. Chang, J. E. Warneke, A. L. Page, and L. J. Lund, "Accumulation of heavy metals in sewage sludge-treated soils," Journal of Environment Quality, vol. 13, no. 1, pp. 87-91, 1984.

[10] F. A. Vega, E. F. Covelo, and M. L. Andrade, "Competitive sorption and desorption of heavy metals in mine soils: influence of mine soil characteristics," Journal of Colloid and Interface Science, vol. 298, no. 2, pp. 582-592, 2006.

[11] Z. L. He, X. E. Yang, and P. J. Stoffella, "Trace elements in agroecosystems and impacts on the environment," Journal of Trace Elements in Medicine and Biology, vol. 19, no. 2-3, pp. 125-140, 2005.

[12] A. Ersoy, T. Y. Yunsel, and M. Cetin, "Characterization of land contaminated by past heavy metal mining using geostatistical methods," Archives of Environmental Contamination and Toxicology, vol. 46, no. 2, pp. 162-175, 2004.

[13] B. J. Alloway and B. E. Davies, "Trace element content of soils affected by base metal mining in wales," Geoderma, vol. 5, no. 3, pp. 197-208, 1971.

[14] C. Kabala and B. R. Singh, "Fractionation and mobility of copper, lead, and zinc in soil profiles in the vicinity of a copper smelter," Journal of Environment Quality, vol. 30, no. 2, pp. 485-492, 2001.

[15] F. Qin, H. Ji, Q. Li, X. Guo, L. Tang, and J. Feng, "Evaluation of trace elements and identification of pollution sources in particle size fractions of soil from iron ore areas along the Chao River," Journal of Geochemical Exploration, vol. 138, pp. 33-49, 2014.

[16] A. Tessier, P. G. C. Campbell, and M. Bisson, "Sequential extraction procedure for the speciation of particulate trace metals," Analytical Chemistry, vol. 51, no. 7, pp. 844-851, 1979.

[17] L. Hernandez, A. Probst, J. L. Probst, and E. Ulrich, "Heavy metal distribution in some French forest soils: evidence for atmospheric contamination," Science of the Total Environment, vol. 312, no. 1-3, pp. 195-219, 2003.

[18] Q. Yao, X. Wang, H. Jian, H. Chen, and Z. Yu, "Characterization of the particle size fraction associated with heavy metals in suspended sediments of the yellow river," International Journal of Environmental Research and Public Health, vol. 12, no. 6, pp. 6725-6744, 2015.

[19] A. R. Cabral and G. Lefebvre, "Use of sequential extraction in the study of heavy metal retention by silty soils," Water, Air, and Soil Pollution, vol. 102, no. 3-4, pp. 329-344, 1998.

[20] L. Rodríguez, E. Ruiz, J. Alonso-Azcárate, and J. Rincón, "Heavy metal distribution and chemical speciation in tailings and soils around a $\mathrm{Pb}-\mathrm{Zn}$ mine in Spain," Journal of Environmental Management, vol. 90, no. 2, pp. 1106-1116, 2009.

[21] L. Q. Ma and G. N. Rao, "Chemical fractionation of cadmium, copper, nickel, and zinc in contaminated soils," Journal of Environment Quality, vol. 26, no. 1, pp. 259-264, 1997.

[22] K. S. Murray, D. Cauvet, M. Lybeer, and J. C. Thomas, "Particle size and chemical control of heavy metals in bed sediment from the rouge river, southeast Michigan," Environmental Science \& Technology, vol. 33, no. 7, pp. 987-992, 1999.

[23] G. Rauret, J. F. López-Sánchez, A. Sahuquillo et al., "Improvement of the BCR three step sequential extraction procedure prior to the certification of new sediment and soil reference materials," Journal of Environmental Monitoring, vol. 1, no. 1, pp. 57-61, 1999.

[24] R. Burt, M. A. Wilson, T. J. Keck, B. D. Dougherty, D. E. Strom, and J. A. Lindahl, "Trace element speciation in selected smelter-contaminated soils in Anaconda and Deer Lodge Valley, Montana, USA," Advances in Environmental Research, vol. 8, no. 1, pp. 51-67, 2003.

[25] R. Burt, T. Weber, S. Park, S. Yochum, and R. Ferguson, "Trace element concentration and speciation in selected mining-contaminated soils and water in Willow Creek floodplain, Colorado," Applied and Environmental Soil Science, vol. 2011, Article ID 237071, 20 pages, 2011.

[26] B. E. Davies and R. C. Ginnever, "Trace metal contamination of soils and vegetables in Shipham, Somerset," The Journal of Agricultural Science, vol. 93, no. 3, pp. 753-756, 1979.

[27] G. A. Upham, "Historical overview of Tennessee's mineral industry: past and present," Journal of the Tennessee Academy of Science, vol. 68, no. 1, 1993.

[28] J. Rodgers, Geology and Mineral Deposits of Bumpus Cove, Unicoi and Washington Counties, State of Tennessee, Department of Conservation, Division of Geology, Hawkins County, TN, USA, 1948.

[29] J. Rodgers, "Geologic map of east Tennessee: Tennessee division,” Geology Bulletin, vol. 58, 1953.

[30] National Weather Service Climate, 2016, http://w2.weather. gov/climate/xmacis.php?wfo=mrx.

[31] K. M. Burdick, "Heavy Metal Contaminants in Surface Drainage at Bumpus Cove," East Tennessee State University, Johnson City, TN, USA, 1993.

[32] ESRI, ArcGIS Desktop: Release 10.1, Environmental Systems Research Institute, Redlands, CA, USA, 2013.

[33] E. O. McLean, "Soil pH and lime requirement," in Methods of Soil Analysis, Part 2. Agronomy Monograph 9, A. L. Page, Ed., pp. 199-223, ASA and SSSA, Madison, WI, USA, 2nd edition, 1982.

[34] D. Ross, "Recommended soil tests for determining exchange capacity," in Recommended Soil Testing Procedures for the Northeastern United States. Northeastern Regional Bulletin \#493. Agricultural Experiment Station, J. T. Sims and A. Wolf, Eds., pp. 62-69, University of Delaware, Newark, DE, USA, 1995.

[35] E. E. Schulte and B. G. Hopkins, "Estimation of soil organic matter by weight loss on ignition," in Soil Organic Matter: Analysis and Interpretation, F. R. Magdoff, M. A. Tabatabai, and E. A. Hanlon Jr., Eds., pp. 21-32, Soil Science Society of America, Madison, WI, USA, 1996.

[36] SPSS, IBM Corporation Released 2016, IBM SPSS Statistics for Windows, Version 23.0, IBM Corporation, Armonk, NY, USA, 2016.

[37] L. Anselin, I. Syabri, and Y. Kho, "GeoDa: an introduction to spatial data analysis," Geographical Analysis, vol. 38, no. 1, pp. 5-22, 2006.

[38] United States Department of Agriculture and Natural Resources Conservation Service, Heavy Metal Soil Contamination. Soil Quality-Urban Technical Note. 3, Soil Quality Institute, Auburn, AL, USA, 2000.

[39] P. R. Whitney, "Relationship of manganese-iron oxides and associated heavy metals to grain size in stream sediments," 
Journal of Geochemical Exploration, vol. 4, no. 2, pp. 251-263, 1975.

[40] R. J. Gibbs, "Transport phases of transition metals in the Amazon and Yukon rivers," Geological Society of America Bulletin, vol. 88, no. 6, pp. 829-843, 1977.

[41] A. K. Singh, S. I. Hasnain, and D. K. Banerjee, "Grain size and geochemical partitioning of heavy metals in sediments of the Damodar River-a tributary of the lower Ganga, India," Environmental Geology, vol. 39, no. 1, pp. 90-98, 1999.

[42] J. N. Moore, E. J. Brook, and C. Johns, "Grain size partitioning of metals in contaminated, coarse-grained river floodplain sediment: Clark Fork River, Montana, USA," Environmental Geology and Water Sciences, vol. 14, no. 2, pp. 107-115, 1989.

[43] M. R. Sharma and N. S. Raju, "Correlation of heavy metal contamination with soil properties of industrial areas of Mysore, Karnataka, India by cluster analysis," International Research Journal of Environment Sciences, vol. 2, no. 10, pp. 22-27, 2013.

[44] M. H. Martin, Biological Monitoring of Heavy Metal Pollution: Land and Air, Springer Science \& Business Media, Berlin, Germany, 2012.

[45] M. Ghosh and S. P. Singh, "A review on phytoremediation of heavy metals and utilization of its byproducts," Asian Journal of Energy and Environment, vol. 6, no. 4, p. 18, 2005.

[46] F. Zeng, S. Ali, H. Zhang et al., "The influence of $\mathrm{pH}$ and organic matter content in paddy soil on heavy metal availability and their uptake by rice plants," Environmental Pollution, vol. 159, no. 1, pp. 84-91, 2011.

[47] A. Navas and J. Machín, "Spatial distribution of heavy metals and arsenic in soils of Aragón (Northeast Spain): controlling factors and environmental implications," Applied Geochemistry, vol. 17, no. 8, pp. 961-973, 2002.

[48] E. R. Orhue and U. O. Frank, "Fate of some heavy metals in soils: a review," Journal of Applied and Natural Science, vol. 3 , no. 1, pp. 131-138, 2011.

[49] V. Antoniadis, J. S. Robinson, and B. J. Alloway, "Effects of short-term $\mathrm{pH}$ fluctuations on cadmium, nickel, lead, and zinc availability to ryegrass in a sewage sludge-amended field," Chemosphere, vol. 71, no. 4, pp. 759-764, 2008.

[50] M. Imperato, P. Adamo, D. Naimo, M. Arienzo, D. Stanzione, and P. Violante, "Spatial distribution of heavy metals in urban soils of Naples city (Italy)," Environmental Pollution, vol. 124, no. 2, pp. 247-256, 2003.

[51] T. Astrup, J. K. Boddum, and T. H. Christensen, "Lead distribution and mobility in a soil embankment used as a bullet stop at a shooting range," Journal of Soil Contamination, vol. 8, no. 6, pp. 653-665, 1999.

[52] X. Cao, L. Ma, M. Chen, D. Hardison, and W. Harris, "Lead transformation and distribution in the soils of shooting ranges in Florida, USA," The Science of the Total Environment, vol. 307, no. 1-3, pp. 179-189, 2003.

[53] P. Ferrandis, R. Mateo, F. R. López-Serrano, M. MartinezHaro, and E. Martinez-Duro, "Lead-shot exposure in redlegged partridge (Alectoris rufa) on a driven shooting estate," Environmental Science \& Technology, vol. 42, no. 16, pp. 6271-6277, 2008.

[54] A. Dube, R. Zbytniewski, T. Kowalkowski, E. Cukrowska, and B. Buszewski, "Adsorption and migration of heavy metals in soil," Polish Journal of Environmental Studies, vol. 10, no. 1, pp. 1-10, 2001. 

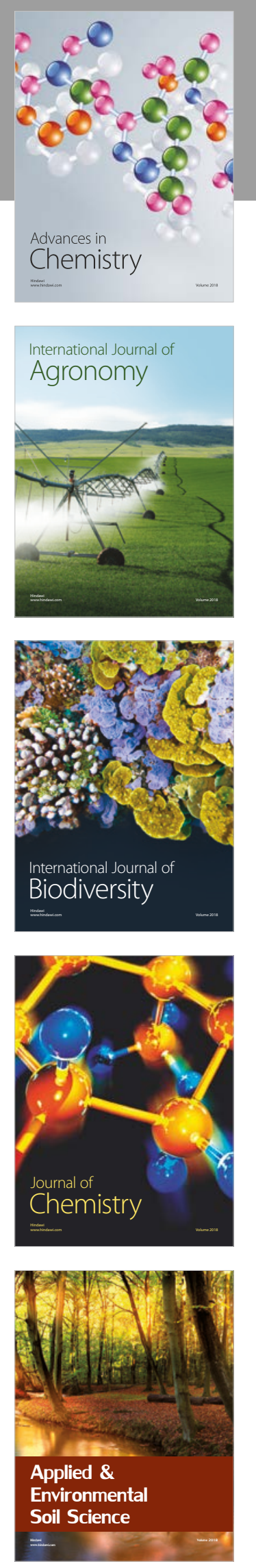

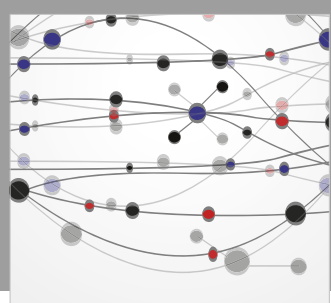

The Scientific World Journal

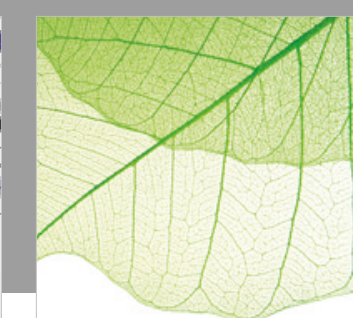

Journal of Botany

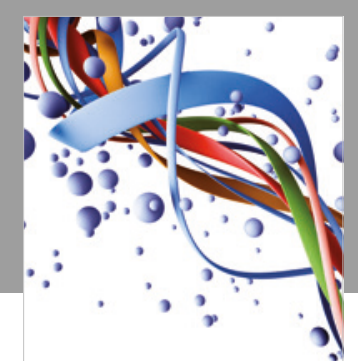

Scientifica

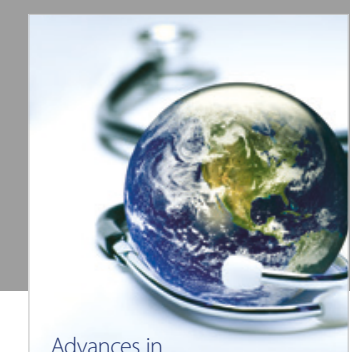

Public Health

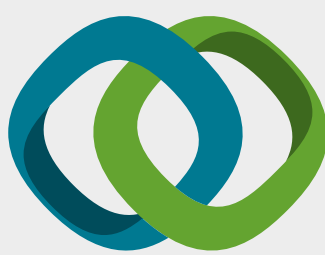

Hindawi

Submit your manuscripts at

www.hindawi.com
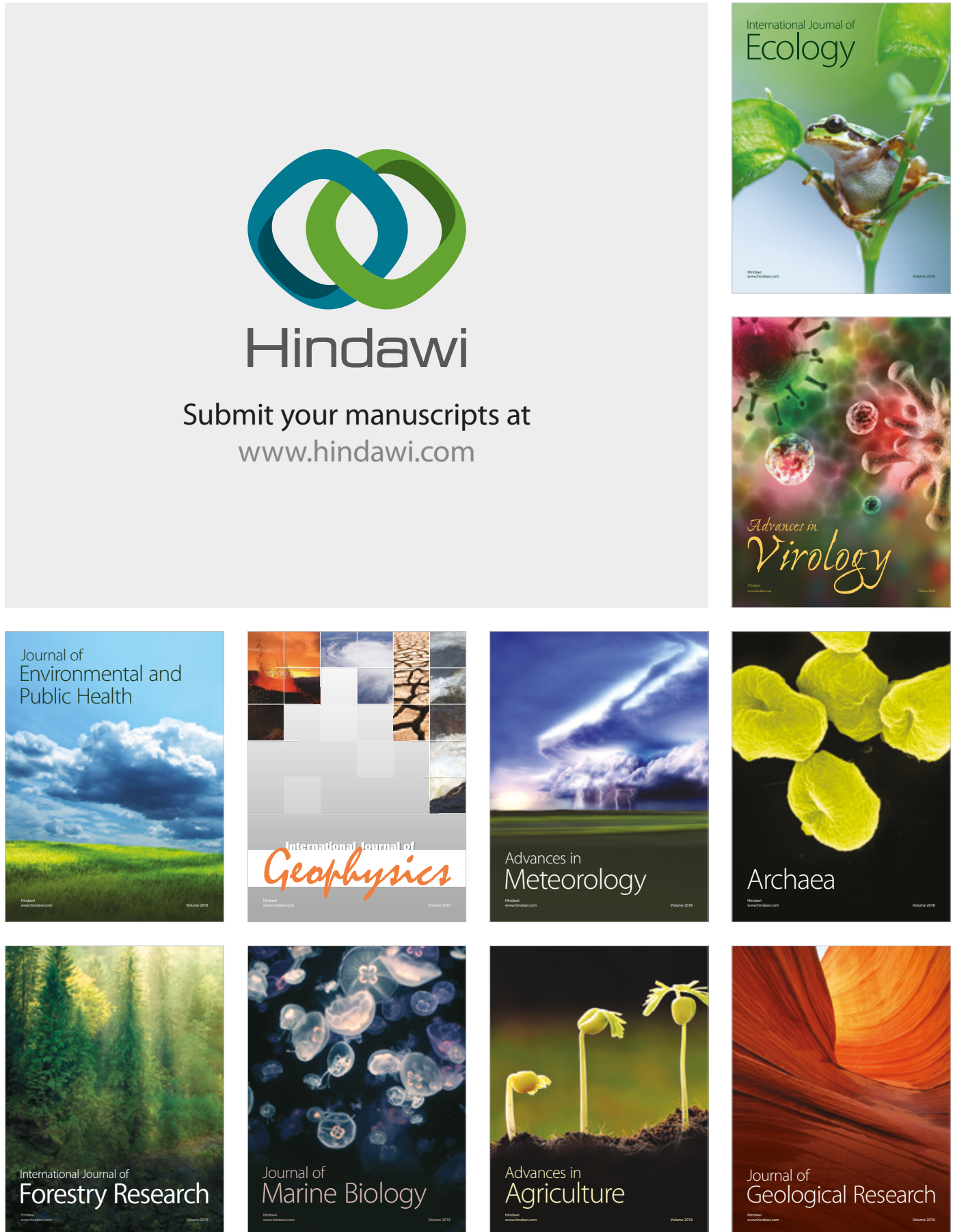

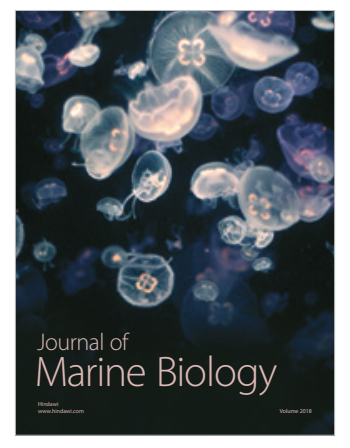

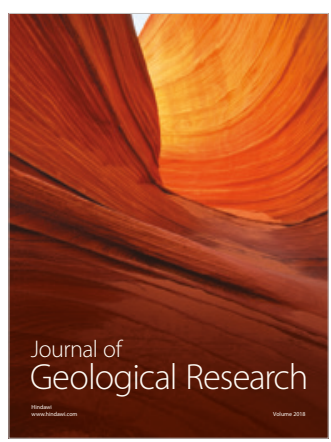

